Dhaka Univ. J. Biol. Sci. 21(2): 17-27, 2012 (January)

\title{
MORPHOGENESIS OF THREE SURFACE-WATER GLEY SOILS FROM THE MEGHNA FLOODPLAIN OF BANGLADESH
}

\author{
Z. H. KhaN*, M. S. Hussain And F. OtTneR ${ }^{1}$ \\ Department of Soil, Water and Environment, University of Dhaka, \\ Dhaka-1000, Bangladesh
}

Key words: Meghna floodplain, Morphogenesis, Soil chemico-physical properties

\begin{abstract}
Surface-water gley soils comprise extensive area on the seasonally wet landscape of Meghna floodplain in Bangladesh. Three typical surface-water gley soils from the above floodplain were studied in the field and laboratory for their pedogenesis. Morphological properties indicate that there is formation of gleyed/ pseudogleyed horizons in the soil profiles. Extensive development of mottles, ploughpans and flood coatings or gleyans is the most notable morphogenetic features in these soils. Physically, these soils are medium to fine textured where textural class ranged between silt loam and silty clay. Chemically, the soils are moderately acidic to neutral in reaction with seasonally fluctuating $\mathrm{pH}$ in the surface horizon. The $\Delta \mathrm{pH}$ values are all negative and range from -0.90 to -2.01 . The organic matter content in the surface soil is relatively low that decreases steadily with depth. The cation exchange capacity (CEC) of the soils ranged from 3.53 to $14.08 \mathrm{cmol} \mathrm{p}+/ \mathrm{kg}$ with an average of $10.10 \mathrm{cmol} \mathrm{p}+/ \mathrm{kg}$ and base saturation per cent (BSP) varied from 59 to 86 . The $\mathrm{Ca}^{++} / \mathrm{Mg}^{++}$ratio is less than unity indicating loss of $\mathrm{Ca}^{++}$ due to gleization in these soils.
\end{abstract}

\section{Introduction}

The surface-water gley soils are agriculturally very important soil group in Bangladesh. They are hydromorphic soils containing less clay and with a seasonally fluctuating $\mathrm{pH}$ in the surface horizon and occur extensively on the seasonally flooded landscapes ${ }^{(1)}$. As per Ramsar Convevtion they are categorized as Wetland soils ${ }^{(2)}$. In the United States the surface-water gleys are categorized as Gray hydromorphic soils, ${ }^{(3)}$ in the southeast Asia as Paddy soils ${ }^{(4)}$ and Aquorizems ${ }^{(5)}$. These soils have aquic moisture regimes and paddy is the dominant crop. Both local and HYVs- are the rice crops grown that support the burgeoning population in the area ${ }^{(6)}$. The present paper deals only with the surface- water gley soils occurring on the Lower Meghna floodplain situated in the Chandpur district of Bangladesh. The Meghna sediments are noncalcareous and are mostly silty. Soils developed on this floodplain differ in their physical and chemical properties mainly due to its mineralogy, age of sedimentation, local relief, drainage and anthropic activity.

*Coresponding author.<khanzh_du@yahoo.com>.

${ }^{1}$ Institute of Applied Geology, University of Natural Resources and Applied Life Sciences, Peter-Jordan Str. 70, 1190 Vienna, Austria. 
Mineralogical properties of these soils were studied (7). The present communication reports a study of the morphology and some chemico-physical characteristics of the soils to ascertain their pedogenesis.

\section{Meterials and Methods}

This study was conducted on the Meghna floodplain soils in Bangladesh. The study area represents smooth, nearly level landscape of floodplain ridges and basins consisting of unconsolidated alluvium. The area under study experiences seasonal flooding of various depths and durations during the monsoon months. Ridges remain mainly above normal flood level while parts remain seasonally shallowly flooded for a period ranging from 1 - 2 months. The basins or basin depressions are flooded more deeply and for a longer period. The climate of the area is humid tropical monsoon with a mean annual temperature of $25.5^{\circ} \mathrm{C}$ and an annual rainfall of around $2250 \mathrm{~mm}^{(8)}$. The temperature regime is hyperthermic and most of the agricultural fields have aquic moisture regime. The area under study had been used for large scale paddy and jute cultivations for centuries. Broadcast aus/jute - transplanted aman followed by Rabi crops and boro - fallow or transplanted aman is the cropping pattern of this area.

The sampling sites were selected to represent major typical surface-water gley soils in the Meghna floodplain. Three profiles from three extensive soil series viz., Tippera, Debidwar and Burichang were selected in three selected sites for soil sample collection. The exact locations of the selected soil profiles and a sketch of the catena as well as the horizons of soil profiles are presented in Fig. 1. Major physical environment of the studied soils is shown in Table 1. Pits were dug in the selected sites and soil profiles were described in the field according to the procedures outlined in the Soil Survey Manual ${ }^{(9)}$. A total of 18 soil samples were collected from the three selected profiles on genetic horizon basis. The samples were processed properly and analysed in the laboratory for determining their physical and chemical properties.

The $\mathrm{pH}$ was determined using glass electrode in soil suspensions in $\mathrm{H}_{2} \mathrm{O}$ and $1 \mathrm{M} \mathrm{KCl}$. The $\Delta \mathrm{pH}$ was calculated by subtracting $\mathrm{pH}$ in $\mathrm{H}_{2} \mathrm{O}$ values from $\mathrm{pH}$ in $\mathrm{KCl}$ values. Particle-size distribution was carried out by sieving and using hydrometer method as per Gee and Bauder ${ }^{(10)}$. Organic carbon was measured by Walkley and Black ${ }^{(11)}$ wet oxidation method and total nitrogen was estimated by digestion of the soil in the sulfuric acid followed by a Kjeldahl distillation ${ }^{(12)}$. Cation exchange capacity (CEC) was measured with $1 \mathrm{~N}$ ammonium acetate solution at $\mathrm{pH}$ 7.0. and exchangeable bases were determined from the same $1 \mathrm{~N}$ ammonium acetate leachate using atomic absorption spectrophotometer ${ }^{(13)}$. Exchangeable $\mathrm{K}^{+}$and $\mathrm{Na}^{+}$were determined with a flame photometer. 


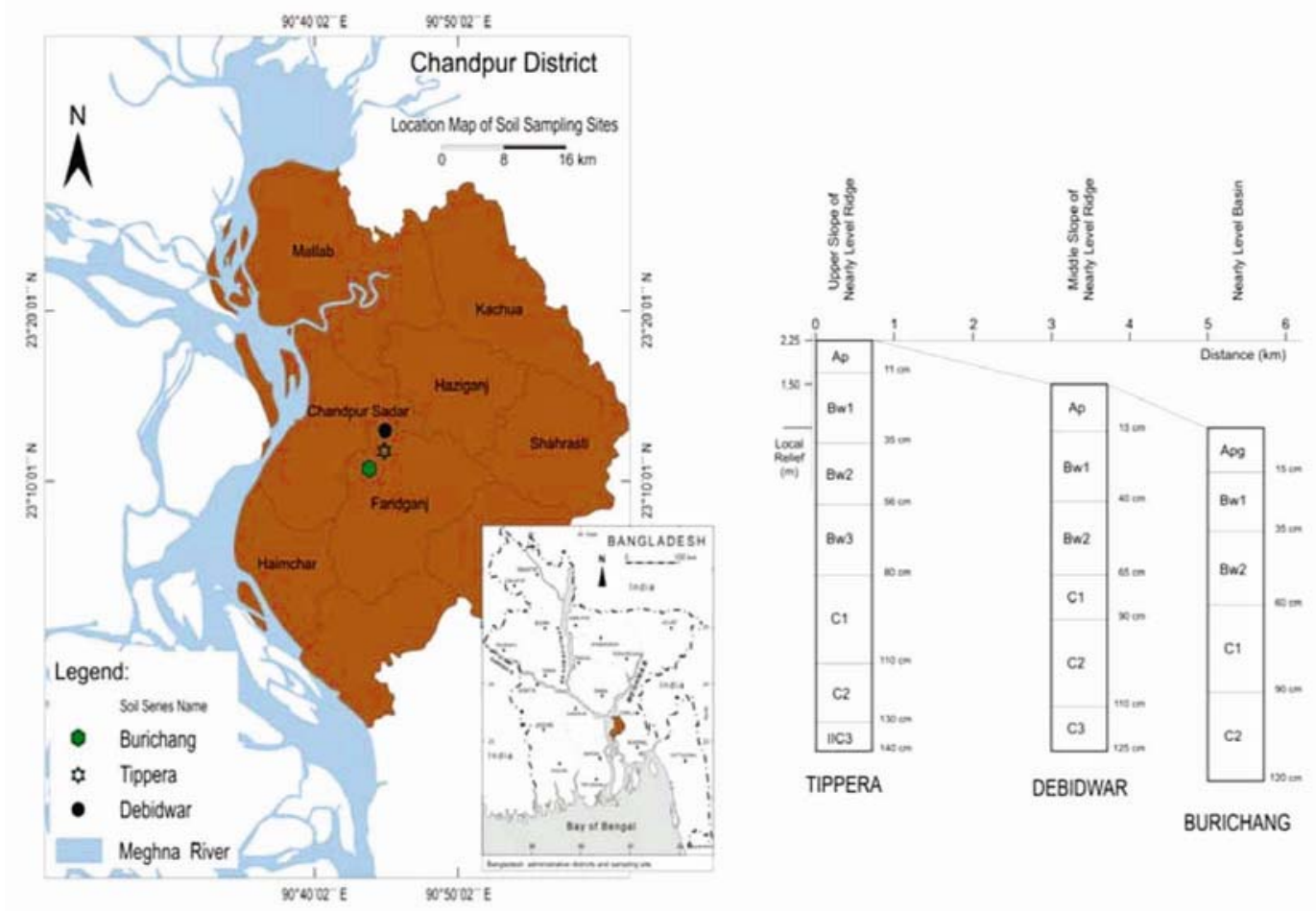

Fig. 1. Location and a sketch of the catena as well as horizons of the soil profiles in the Meghna floodplain in Bangladesh.

\section{Results and Discussion}

Some salient morphogenetic features of the three surface-water gley soils from the Meghna floodplain of Bangladesh have been presented in Table 2. Oxidation during the dry season and reduction during the wet season are the two usual conditions in these soils. The soils exhibit gray matrix colour with value 3 to 5 and chroma 1 to 3 possibly due to prolonged submergence and subsequent development of reducing conditions during the flooding season. Moreover, all the soils have dark brown to dark yellowish brown mottles, prominent in the middle zone of the profiles, where oxidation-reduction conditions alternate. The alternate wetting and drying conditions in the soils resulted in release of Fe from iron-bearing minerals which in turn was precipitated and fixed in the form of mottles in the subsurface horizons ${ }^{(14)}$. Surface gleying (pseudogleys) and subsurface grayization (gleys) are the most notable morphometric features in these soils. A low chroma of the matrix is generally associated with the gleying phenomena of the soils. Stoops and Eswaran(15) noted that with increasing hydomorphism Fe hydroxide segregations appear in the groundmass and low chromas in the peds. The presence of gleyed/pseudogleyed layers and mottlings near the surface horizons of the studied soils indicates that these soils have hydromorphic properties ${ }^{(1)}$. Joffe ${ }^{(16)}$ noted that the presence 


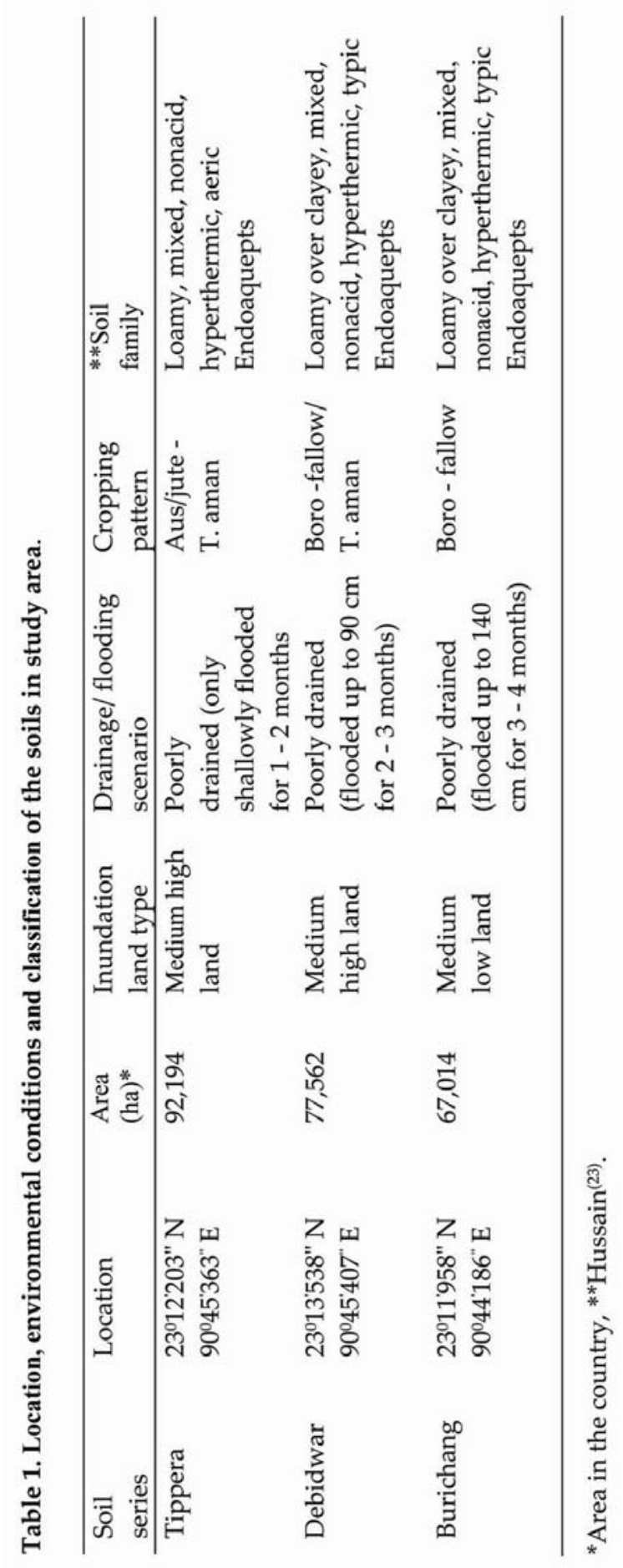




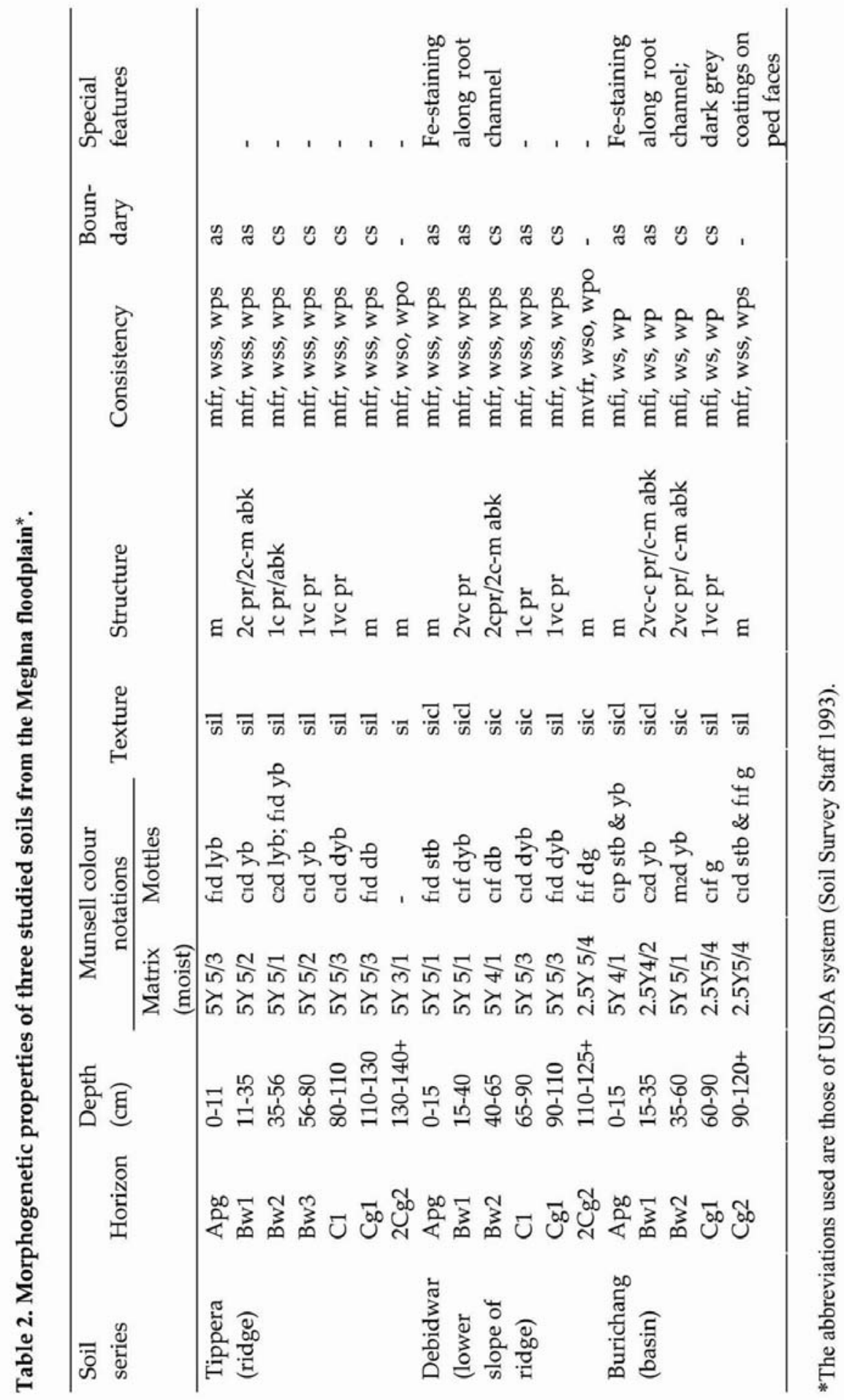


of mottles indicate fluctuation of ground water table while the presence of gleys in the lower zone is an unfailing indication of perennial hydromorphism.

Moreover, all the soils have continuous, thick, grey to dark grey flood coatings on structural ped faces due to mechanical down washings of unoriented clay, fine silt and humus when the soils get flooded and ploughed(6). This coatings form quite rapidly and generally have the same colour and mineralogy as the top soils. The name gleyans has been proposed for these flood coating since the coating material is always gleyed (reduced) $)^{(6)}$.

Ploughpan is a special morphogenetic (anthropogenic) features in these soils. Plough pan - a compact slowly permeable layer - below the Ap horizon has been formed due to puddling by using traditional ploughs to which the soils were subjected to for transplanted paddy cultivation. The plough pan being less permeable and compact is favourable for transplanted paddy cultivation but this compact layer restricts penetration of crop root below to harness moisture and nutrients present in the lower layers. On all landscape puddling for rice cultivation apparently accelerates the processes giving rise to the albic horizon and concentrate them in the ploughed layer and ploughpan ${ }^{(1)}$.

Albic horizons are known to be developed in many mature surface- water gley soils of Bangladesh ${ }^{(1)}$. The seasonal alternate wetting and drying cycles create a condition for transformation of $\mathrm{Fe}^{++}$to $\mathrm{Fe}^{+++}$that finally causes decomposition of clay. This process has been designated as ferrolysis by Brinkman ${ }^{(1)}$. The net result of ferrolysis is the lowering of clay fraction with a subsequent lowering of cation exchange capacity of soils thus affected.

The soils are medium to fine textured, where textural class ranged between silt loam and silty clay. The structure is massive in the surface horizons because of ploughing for many years with puddling. A moderate medium to coarse prismatic and blocky structure has developed in the B horizons. Alternate wet and dry periods favour the formation of structural peds in these soils( ${ }^{(6)}$. Pedogenetically these soils have developed properties of cambic horizon under the ochric epipedon.

Consistencies of soils occurring in the floodplain ridges (e.g. Tippera and Debidwar series) are friable, slightly sticky and slightly plastic while the consistencies of soils occurring on basin bottoms (e.g. Burichang series) are firm, sticky and plastic, depending on the clay content. All the soil profiles showed abrupt to clear and smooth horizon boundaries, reflecting young soil development or rejuvenation processes.

The soils contained large quantities of silt, ranging from 47 to $86 \%$, with an average of $63 \%$ (Table 3). Based on silt content the studied soils show the following gradation along the catena: Burichang $>$ Debidwar $>$ Tippera. These high silt content is a characteristic property of the floodplain soils of Bangladesh(17). The clay content ranged from 8 to $48 \%$, with an average of $28 \%$. High values of clay are found in the Burichang soils occurring on basin bottoms while 


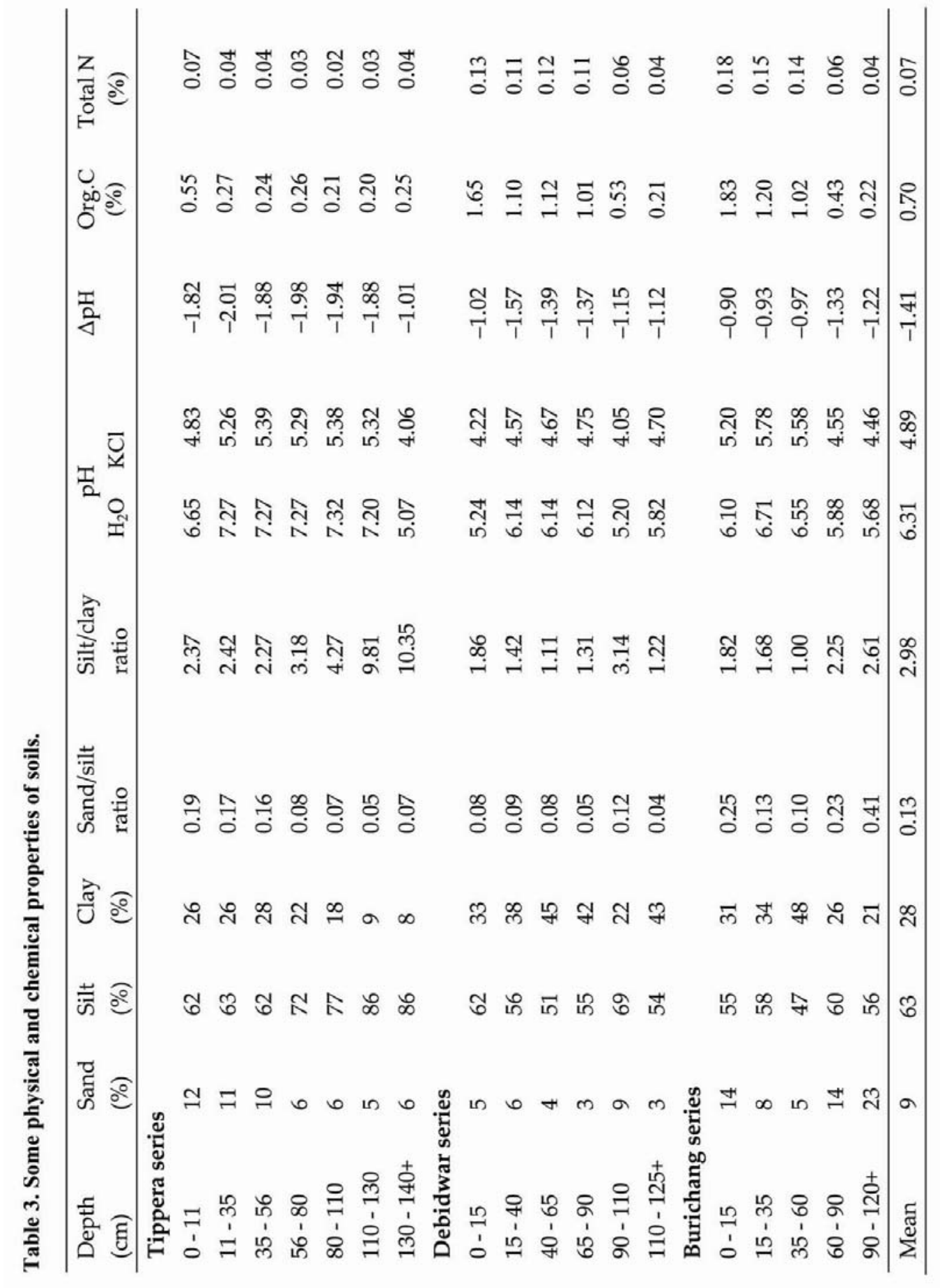


low values are found in the Tippera and Debidwar series occurring on floodplain ridges. Based on clay content the soils showed the following gradation: Tippera $>$ Debidwar $>$ Burichang. In general the ridge soils have silt loam to silty clay loam texture while the basin soils are clayey ${ }^{(18)}$. The rather erratic vertical distribution of particle size components indicate the heterogeneity and lithological discontinuity of the sediments and the turbulent condition under which they were deposited. The silt/clay ratio in many horizons varied erratically (1.00 to 10.35) and indicated that the observed variation of silt/clay ratio is lithological rather than weathering of silt into clay in situ. The sand/silt ratio of the soils is less than 1.0 with a mean value of 0.13 .

Surface impoverishment of clay is quite a noticeable feature in these soils. But it is difficult to predict if these impoverishment has been caused by the ferrolysis/gleization processes. Impoverishment of clay in the surface horizons of the soil profiles is a common feature in the mature surface-water gley soils where ferrolysis is a common soil forming process ${ }^{(1)}$.

The studied soils were moderately acidic to neutral with $\mathrm{pH}$ values ranging from 5.07 to 7.32 (Table 3). In all profiles, there was a trend of increasing $\mathrm{pH}$ up to a certain depth. This increase in $\mathrm{pH}$ with depth is a common feature in most of the surface-water gley soils of Bangladesh where ferrolysis is a common soil forming process ${ }^{(1)}$. Ponnamperuma ${ }^{(19)}$ noted that acidification of topsoil is caused by continual displacement of bases by ferrous iron during the anaerobic or reduction phase associated with annual flooding. An observed decline of $\mathrm{pH}(1 \mathrm{~N} \mathrm{KCl})$ in all the soils and the $\Delta \mathrm{pH}$ values are presumed to be due to the difference in reserve acidity.

The organic carbon contents in the soils is low and range from 0.21 to $1.83 \%$ (Table 3). These results are in agreement with those reported for soils from the floodplains of Bangladesh ${ }^{(17)}$. Most mineral wetland soils of tropical Asia have only up to $3 \%$ organic matter content, but this amount influences productivity to nearly the same degree as the inorganic constituents ${ }^{(20)}$. The seasonally flooded soils of Bangladesh are presently puddled using the mechanical or traditional ploughs to cultivate transplanted paddy ${ }^{(6)}$. Consequently, paddy straws are smeared in the topsoil in large quantity. Due to addition of paddy straw having wide $\mathrm{C} / \mathrm{N}$ ratio the microbial activities in topsoil are augmented as the microbes can derive adequate energy from the added paddy straw. The phenomenon depletes the soil nitrogen content as the microbes derive the needed nitrogen for cell formation from the soil humus.

Highest amount of organic carbon is found in the surface horizon of basin soils (e.g. Burichang profile) whereas the lowest content is found in the ridge soils (e.g. Tippera profile). Low organic carbon content is a problem in Bangladesh soils, which is possibly due to rapid decomposition of organic matter under hyperthermic temperature regime. The total nitrogen content in the soils ranged from 0.02 to $0.18 \%$ with an average of $0.07 \%$ (Table 3 ). As expected the vertical distribution patterns of total nitrogen follows closely the sequence of organic carbon.

The CEC of the soils ranged from 3.53 to $14.08 \mathrm{cmol} \mathrm{p} / \mathrm{kg}$, with an average of $10.10 \mathrm{cmol}$ $\mathrm{p}^{+/ \mathrm{kg}}$ (Table 4). Higher values of CEC occurred in the sub-surface horizons of Burichang profile 
while lower values are found in the sub-surface horizons of Tippera profile. The CEC in these soils bears a significant positive correlation with the clay contents $\left(\mathrm{r}=0.87^{* *}\right)$. The $\mathrm{Mg}^{2+}$ in some horizons of the profiles was the dominant cation in the exchange phase of these soils followed by $\mathrm{Ca}^{2+}$ and $\mathrm{K}^{+}$. It has been reported that, under the gleization process of soil formation, exchangeable $\mathrm{Mg}^{2+}$ becomes the dominant cation in the exchange complex ${ }^{(21)}$. In the studied surface-water gley soils the mean $\mathrm{Ca}^{2+} / \mathrm{Mg}^{2+}$ ratio is 0.85 (Table 4). The $\mathrm{Ca}^{2+} / \mathrm{Mg}^{2+}$ ratio is less than unity indicating loss of $\mathrm{Ca}^{++}$due to gleization in these soils. Buol et al. ${ }^{(22)}$ reported that the $\mathrm{Ca}^{2+} / \mathrm{Mg}^{2+}$ ratio in the soil decreases with increasing maturity. The soils have very high percentage of base saturation.

Table 4. Charge characteristics of the surface-water gley soils from Meghna floodplain.

\begin{tabular}{|c|c|c|c|c|c|c|c|c|}
\hline \multirow{2}{*}{$\begin{array}{l}\text { Soil } \\
\text { series }\end{array}$} & \multirow{2}{*}{$\begin{array}{l}\text { Depth } \\
(\mathrm{cm})\end{array}$} & CEC & $\mathrm{Ca}^{++}$ & $\mathrm{Mg}^{++}$ & $\mathrm{Na}^{+}$ & $\mathrm{K}^{+}$ & \multirow{2}{*}{$\begin{array}{c}\mathrm{Ca}^{++} / \mathrm{Mg}^{++} \\
\text {ratio }\end{array}$} & \multirow[t]{2}{*}{ BSP* } \\
\hline & & \multicolumn{5}{|c|}{$\mathrm{cmol} \mathrm{p}^{+/ \mathrm{kg}}$} & & \\
\hline \multirow[t]{7}{*}{ Tippera } & $0-11$ & 9.12 & 3.58 & 3.33 & 0.09 & 0.14 & 1.07 & 78 \\
\hline & $11-35$ & 11.30 & 3.80 & 5.24 & 0.10 & 0.15 & 0.73 & 82 \\
\hline & $35-56$ & 10.84 & 4.04 & 4.65 & 0.09 & 0.18 & 0.87 & 83 \\
\hline & $56-80$ & 8.53 & 3.76 & 2.61 & 0.07 & 0.11 & 1.44 & 77 \\
\hline & $80-110$ & 7.80 & 2.97 & 2.66 & 0.07 & 0.13 & 1.12 & 76 \\
\hline & $110-130$ & 6.67 & 3.13 & 1.57 & 0.06 & 0.13 & 1.99 & 73 \\
\hline & $130-140+$ & 3.53 & 1.20 & 0.69 & 0.05 & 0.15 & 1.74 & 59 \\
\hline \multirow[t]{6}{*}{ Debidwar } & $0-15$ & 10.13 & 3.94 & 3.73 & 0.28 & 0.18 & 1.06 & 80 \\
\hline & $15-40$ & 13.93 & 4.45 & 6.80 & 0.37 & 0.21 & 0.65 & 85 \\
\hline & $40-65$ & 14.50 & 4.66 & 7.13 & 0.41 & 0.22 & 0.65 & 86 \\
\hline & $65-90$ & 15.30 & 4.66 & 7.81 & 0.46 & 0.19 & 0.60 & 86 \\
\hline & $90-110$ & 7.53 & 1.81 & 2.95 & 0.32 & 0.33 & 0.61 & 72 \\
\hline & $110-125+$ & 14.63 & 4.25 & 7.16 & 0.49 & 0.13 & 0.59 & 82 \\
\hline \multirow[t]{6}{*}{ Burichang } & $0-15$ & 14.08 & 6.52 & 4.55 & 0.87 & 0.14 & 1.43 & 86 \\
\hline & $15-35$ & 12.99 & 4.03 & 5.30 & 1.16 & 0.39 & 0.76 & 84 \\
\hline & $35-60$ & 14.95 & 4.48 & 6.60 & 1.67 & 0.28 & 0.68 & 87 \\
\hline & $60-90$ & 6.58 & 1.83 & 2.64 & 0.98 & 0.23 & 0.69 & 86 \\
\hline & $90-120+$ & 5.70 & 1.44 & 1.44 & 0.87 & 0.14 & 1.00 & 68 \\
\hline & Mean & 10.45 & 3.59 & 4.27 & 0.47 & 0.19 & 0.85 & 79 \\
\hline
\end{tabular}

*Base saturation per cent.

Parent material and the conditions like poor drainage and aquic moisture regime due to regular inundation during the rainy season are probably the factors moulding the morphogenesis of the soils. Parent materials were of mixed origin and were at an incipient stage. The seasonal submergence and drying set the conditions of alternate oxidation and reduction which are the most striking feature of the pedochemical environment in these soils. The presence of gleys, mottles and flood coatings or gleyans indicates that there is 
hydromorphism in these soils. The process of hydromorphism in the soils is mainly attained due to the reduction and/or loss of iron and manganese and the development of grey colours.

Alternate wet and dry conditions produce vertical cracks leading to big prisms in the soil profiles. With the passage of time, the horizontal cracks and combined effect of flocculation, root penetration, organic matter addition and the biotic activity produced angular and sub-angular blocky structures in the studied soils. These structural B horizons have been considered as cambic B horizons. Formation of structure in these soils is relatively faster than in other soils. ${ }^{(6)}$ The structure is massive in the surface horizons because of ploughing for many years with puddling. Structurelessness in the lower most horizons was also observed in these soils.

The reaction of the soils closely follows the course of oxidation-reduction conditions because the soils contain considerable amounts of $\mathrm{Fe}$ and $\mathrm{Mn}$ which are subject to change. Alternate wetting and drying conditions in the soils resulted in release of Fe from iron-bearing minerals which in turn was precipitated and fixed in the form of mottles in the subsurface horizons of soils. This kind of mobilization and fixation of iron indicates that gley horizons occur in the deeper zone of the soils in the permanent ground water zone. Gleization can possibly be designated as the major pedogenic process in these soils. The low exchangeable $\mathrm{Ca}^{++} / \mathrm{Mg}^{++}$ratio, massive structure in the topsoil and structurelessness in the lowermost horizon of these soils also support this fact ${ }^{(21)}$.

\section{References}

1. Brinkman R 1977. Surface-water gley soils in Bangladesh: Genesis. Geoderma 3: 199-206.

2. Ramsar Convention Bureau 2000. Ramsar Handbooks for the wise use of wetlands. Gland, Switzerland.

3. Hussain MS and D Swindale 1970. A morphological and mineralogical study of the gray Hydromorphic soils of the Hawaian Islands. Pacific Sci. 24: 543-553.

.4. Kawaguchi $\mathrm{K}$ and $\mathrm{K}$ Kyuma 1968. Fertility characteristics of lowland rice soils in some southern Asian countries. Trans. Int. Congr.Soil Sci., 9th, Adelaide, IV: 19-31.

.5. Kawaguchi K and K Kyuma 1969. Lowland Rice Soils in Thailand. The Centre for Southeast Asian Studies. Tokyo University, Japan. 270 p.

6. Brammer H 1996. The geography of the soils of Bangladesh. The University Press Limited, Dhaka, Bangladesh. p. 287.

7. Khan ZH and F Ottner 2010. Mineralogical composition of three soil series from the Meghna floodplain of Bangladesh and the soil management implications. Bangladesh J. Sci. Res. 23(2): 115-128.

8. FAO-UNDP 1988. Land Resources Appraisal of Bangladesh for Agricultural Development. Reports 2 and 3. Agroecological regions of Bangladesh. FAO, Rome.

9. Soil Survey Staff. 1993. Soil Survey Manual. USDA Soil Survey Divisions. Agricultural Handbook 18, US Govt. Printing Office, Washington, D.C. 437pp. 
10. Gee, GW and JW Bauder 1986. Particle size analysis. In: Methods of Soil Analysis. Part 1. 2nd ed. A Klute (ed.) Agronomy 9: 383-411.

11. Walkley A and CA Black 1934. An examination of the Degtijareff method for determining soil organic matter and a proposed modification of the chromic acid titration method. Soil Sci. 37: 29-38.

12. Bremner JM and CS Mulvary 1982. Nitrogen-Total. In: Methods of Soil Analysis. Part 2. 2nd ed. AL Page, RH Miller and DR Keeney (eds.) Agronomy 9: 595-624.

13. Rhoades JD 1982. Cation exchange capacity. In: Methods of Soil Analysis. Part 2. 2nd ed. AL Page, RH Miller and DR Keeney (eds.) Agronomy 9: 149-157.

14. Wilding LP and JL Rehage 1985. Pedogenesis of soils with aquic moisture regimes. In: Wetland Soils-Characterizatoin, Classification and Utilization. International Rice Research Institute (IRRI), Los Banos, Philippines. pp. 139-157.

15. Stoops G and H Eswaran 1985. Morphological characteristics of wet soils. In: Wetland SoilsCharacterizatoin, Classification and Utilization. International Rice Research Institute (IRRI), Los Banos, Philippines. pp. 177-189.

16. Joffe JS. 1968. Pedology. Pedology Publications. New Brunswick, New Jersey. pp. 662.

17. Khan ZH, AR Mazumder, MS Hussain and SM Saheed 1998. Physical properties of some benchmark soils from the floodplains of Bangladesh. J. Indian Soc. Soil Sci. 46(3): 421-424.

18. SRDI Staff. 1965-1986. Reconnaissance soil survery reports of different districts of Bangladesh. Soil Resources Development Institute (SRDI). Farmgate, Dhaka.

19. Ponnamperuma FN 1985. Chemical kinetics of wetland rice soil relative to soil fertility. In: Wetland Soils-Characterizatoin, Classification and Utilization. International Rice Research Institute (IRRI), Los Banos, Philippines. pp. 71-90.

20. Neue HU 1985. Organic matter dynamics in wetland soils. In: Wetland Soils-Characterizatoin, Classification and Utilization. International Rice Research Institute (IRRI), Los Banos, Philippines. pp. 109-122.

21. Saunders WMH 1959. On gleying. N.Z. Soil News 2: 58-60.

22. Buol SW, FD Hole, RJ McCracken and RJ Southard 2001. Soil Genesis and Classification. $5^{\text {th }}$ ed. Iowa State University Press, Ames, Iowa. pp. 527.

23. Hussain MS 1992. Soil Classification with Special Reference to the Soils of Bangladesh. Dhaka Univ. Press. pp. 345.

(Manuscript received on 28 May, 2011; revised on 24 August, 2011) 